\title{
LINKING SELECTIVE HIRING TO ORGANIZATIONAL COMMITMENT: EVIDENCE FROM THE HOTEL INDUSTRY OF MALAYSIA
}

\author{
Aizzat Mohd. Nasurdin \\ School of Management \\ Universiti Sains Malaysia
}

\author{
Noor Hazlina Ahmad \\ School of Management \\ Universiti Sains Malaysia
}

\author{
Tan Cheng Ling \\ Graduate School of \\ Business \\ Universiti Sains Malaysia
}

\section{ABSTRACT}

This study investigates the relationship between selective hiring and organizational commitment. Analysis using Partial Least Squares technique of data from 290 frontline hotel employees in Peninsular Malaysia revealed that selective hiring has a significant positive effect on organizational commitment. Theoretical discussion, practical implications, limitations, and directions for future research are provided.

Key Words: Organizational commitment, selective hiring, frontline employees, hotels, Malaysia.

\section{INTRODUCTION}

Since 1990, the Malaysian government has been putting great effort in promoting Malaysia as a worldwide tourist destination in its attempt to multiply the source of national income. Since then, a rapid growth in the number of tourist arrivals to Malaysia has been observed (Ministry of Tourism and Culture Malaysia, 2014). The increase in tourist arrivals has spurred private companies to invest into the hotel business in Malaysia because accommodation accounts for about 31 percent of tourists' spending as reported by the Ministry of Tourism (2011). As a consequence, the number of hotels in Malaysia soared from 1492 units in 2000 to 2724 units in 2012(Tourism Malaysia, 2014). The development of hotel establishments has stepped up competition. Since hotels provide nearly identical services, one way in which they can distinguish themselves is on the basis of service quality. In fact, $\mathrm{Ma}$ and Qu (2011) suggested that delivering service of high quality is the key competitive strategy for hotels. Because of this, hotels need to have a committed and loyal workforce. Maxwell and Steele (2003) asserted that in a dynamic, service-oriented context such as that of the hotel industry, securing employee commitment will ultimately improve organizational performance and success. According to Maxwell and Steele (2003), commitment positively affect employee performance since committed employees expressed persistence in completing their in-role tasks and achieving goals, more prepared to accept change, and more willing to assume extra-role tasks. Within the service environment, these outcomes will lead to enhanced service quality. Since frontline employees have direct and frequent face-to-face interactions with customers, they play a crucial role in linking a firm with its customers and thus in building good relationships. In other words, employees' level of commitment will have a major influence on customers' perceptions of service quality and subsequent satisfaction. As previously mentioned, since commitment affect performance, it would be to the hotel's best interest to secure employee commitment. Therefore, there is a great need to understand factors that elicit their commitment.

A review of the existing literature indicates that organizational commitment brings about in functional outcomes. According to scholars (Fiorito, Bozeman, Young, \&Meurs, 2007; Kazlauskaite, 
Buciuniene, \& Turauskas, 2006; Lee, Nam, Park, \&Lee, 2006; Mowday, 1998; Paulin, Ferguson, \& Bergeron, 2006; Schneider \&Bowen, 1985; Singh, 1998), frontline employees who possess higher organizational commitment are bound to embrace the firm's customer-oriented values, observed better attendance, tend to stay longer with the organization, exhibit lower levels of role stress, more likely to exhibit extra-role behavior, and deliver the highest level of service quality. As a result, organizational commitment has emerged as an important construct in organizational research.

Organizational commitment is defined in terms of the relative strength of an individual's identification with and involvement in a particular organization (Mowday, Steers, \&Porter, 1979). Basically, organizational commitment is considered to be a bond linking the individual to the organization (Mathieu \&Zajac, 1990). A perusal of the extant literature indicates that in a majority of these studies, organizational commitment has been viewed as a general affective response of an employee to the organization as a whole. In other words, this form of commitment is referred to as affective commitment. Given the importance of commitment, Mathieu and Zajac (1990) in their metaanalysis have identified several categories of antecedents which include personal characteristics, job/role characteristics, group-leader relations, and organizational characteristics. Of these, the effective management of a firm's human resources has been advocated by some authors (Harter, Schmidt, \&Hayes, 2002; Huselid, 1995) as a strategic move for firms to generate greater knowledge, motivation, synergy, and commitment among their workforce. This is because human resource management (henceforth labelled as HRM) practices create conditions where employees become highly involved in the organization and work hard to accomplish the organization's goals. According to several scholars (Boon, Belschak, Den Hartog, \&Pijnenburg, 2014; Morrison, 1996; Snape \&Redman, 2010), how an organization manages its human resources (which can be discerned from its HRM practices) sets the tone and conditions of the employee-employer relationship. When such relationship is regarded as that of social exchange (Blau, 1964) where the norm of reciprocity (Gouldner, 1960) applies, employees would be more likely to become committed to their organization.

Despite the importance of HRM practices, its potential impact in stimulating employees' commitment has received far less attention than it deserves (Meyer \&Smith, 2000). Moreover, Mowday(1998) calls for more studies linking HRM practices and employee commitment at both the organizational and individual-level of analyses. Although many HRM practices have been identified as possible predictors of organizational commitment, in this study, our focus is on selective hiring. This is because as noted by Berger and Ghei (1995), selecting and hiring effective employees is critical to successful hotel operation. According to Berger and Ghei (1995), while effective employees can work in and around inefficient organizational structures, even the best organization functions poorly when staffed with ineffective employees. This is more so for hospitality organizations such as hotels, where poor performing employees would have a detrimental effect on customer satisfaction. Moreover, since labor turnover has been shown to be unacceptably high in the hotel industry (Kennedy \&Berger, 1994), hiring practice is considered an essential tool in addressing labor shortage. In addition, most of the research on commitment was carried out in western setting such as that of North America (Meyer, Stanley, Herscovitch, \&Topolnytsky, 2002). Since cultural differences may play a role in explaining the antecedents of employee commitment (Chan, Tong-qing, Redman, \&Snape, 2006), the present study, which provides empirical evidence from a Malaysian context, would be able to enrich the existing literature. In light of the above-mentioned gaps, the significant contribution of the tourism industry to Malaysia's national income, the need for hotels to retain their employees and remain competitive, and the key role of frontline employees' attitudes in delivering services to customers, this study seeks to explore the effect of selective hiring on organizational commitment of frontline hotel employees in Malaysia. 


\title{
LITERATURE REVIEW
}

\author{
Organizational Commitment
}

The concept of organizational commitment has been defined in many ways (Allen \&Meyer, 1990; Mathieu \&Zajac, 1990; O'Reilly \&Chatman, 1986; Reichers, 1985). According to Mowday et al. (1979), the concept of commitment can be characterized by at least three factors: (a) a strong belief in, and acceptance of, the organization's goals and values, (b) a willingness to exert considerable effort on behalf of the organization; and (c) a strong desire to remain in the organization. This form of commitment is viewed as unidimensional and focuses on the affective attachment between the individual and the organization. Other scholars, however, have expanded the commitment conceptualization to include other forms of attachment. For example, Allen and Meyer (1990) distinguished between three forms of commitment: affective, continuance, and normative. O'Reilly and Chatman (1986) suggested that the bond between an employee and the organization could take three forms: compliance, identification, and internalization. Nevertheless, these conceptualizations have some overlaps. Mowday (1998) in his review of organizational commitment noted that his earlier approach to commitment as reported in Mowday et al. (1979) is similar to O'Reilly and Chatman's (1986) internalization dimension and Allen and Meyer's (1990) concept of affective commitment. A review of the literature indicates that affective commitment is the most commonly studied type of commitment.

\section{Human Resource Management (HRM) Practices}

The influence of HRM practices on performance at the organizational, group, and individual level is an important topic in the fields of human resource management, industrial relations, and industrial and organizational psychology. Basically, HRM practices have been viewed as organizational activities that are directed at managing the pool of human resources and ensuring that resources are employed towards the fulfilment of organizational goals (Schuler \&Jackson, 1987). Within the hospitality literature,HRM practices refer to an individual's perceptions of the extent of implementation of the strategies, plans, and programs used to attract, motivate, develop, reward, and retain the best people to meet organizational goals (Dittmer, 2002). Despite its eminence, Kusluvan, Kusluvan, Ilhan, and Buyruk (2010)asserted that the hospitality industry has been reputed to have poor HRM practices.

In the hospitality literature, several studies have examined the effects of individual HRM practices on employee commitment, which include empowerment (Kazlauskaite et al., 2006; Yang, 2012), career mentoring/development (Chew \&Wong, 2008; Hemdi, 2009), recognition (Yang, 2012), competence development/training (Doug, Ruth, \&Lawson, 2001; Hemdi, 2009; Roehl \&Swerdlow, 1999; Yang, 2012), compensation/rewards (Doug et al., 2001; Walsh \&Taylor, 2007; Yang, 2012), information sharing (Yang, 2012), orientation (Lundberg \&Young, 1997), and performance appraisal (Doug et al., 2001; Hemdi, 2009). To our knowledge, none have looked into the impact of hiring practices on employee commitment. Moreover, despite the influential role of the above-mentioned HRM practices on commitment, we are of the opinion that selective hiring should be a major concern for hotels. This is because faulty and inadequate hiring processes have been identified as one of the main causes of turnover (Groves, Martin, \&Beck, 2001). In addition, there is little evidence of systematic selection practice to identify quality service attributes among potential employees in the hotel industry (Lockyer \&Scholarios, 2004). Besides, several scholars (Allen \&Meyer, 1990; Louis, 1980; Wanous \&Reichers, 2000) have noted that the early stage of employees' experience in the organization is an important determinant in shaping employees' subsequent attitudes and behaviors. This choice of specific practice is deemed appropriate especially in the Malaysian hotel industry which is plagued with the problem of high employee turnover as remarked by Ahmad and Scott (2014). According to Ahmad and Scott (2014), the need to resolve labor shortages 
has driven hotels to continually hire people for replacement purposes. Bearing this in mind, our focus is on the role of selective hiring in eliciting organizational commitment.

\section{Selective Hiring and Organizational Commitment}

Selective hiring refers to the rigor of hiring as indicated by applications per vacancy (Fiorito et al., 2007). Selective hiring involves several activities, which include careful matching between job applicant and job requirements, a conscious attempt to attract the best talent from the job market, as well as offering higher compensation to retain the talent in the organization (Fiorito et al., 2007). In the present study, selective hiring may have a positive effect on organizational commitment of employees based on two major reasons. First, when employees realized that the organization has invested substantial effort and costs in selecting them, they may believe that the organization values them and is committed to them (Fiorito et al., 2007). As a result, employees may experience a felt obligation to repay the organization through increased commitment (Aryee, Budhwar, \&Chen, 2002; Eisenberger, Armeli, Rexwinkel, Lynch, \&Rhoades, 2001). Second, the careful match between job applicant and organization's values would result in a person-organization fit, which may help new employees to accept and believe in organizational goals and values, which in turn, lead to greater commitment (Caldwell, Chatman, \&O'Reilly, 1990; Dessler, 1999; Kazlauskaite et al., 2006; O'Reilly \&Chatman, 1986). This line of argument is evidenced in the study by Iplik, Jilic, and Yalcin (2011) who found that managers in Turkish five-star hotels who reported to have higher person-organizational fit showed higher organizational commitment and experienced lower stress level. A meta-analysis by Verquer, Beehr, and Wagner (2003) demonstrated that employees are more committed to the organization when their values are in congruence with that of their organization. In a study using a sample of 291 respondents from 45 firms, Caldwell et al. (1990) demonstrated that rigorous recruitment and selection procedures were associated with higher levels of employee commitment. Thus, we propose the following hypothesis:

$\mathrm{H}_{1}$ : Selective hiring will be positively related to the level of organizational commitment.

\section{METHODOLOGY}

\section{Sample and Data Collection Procedure}

Based on the directory of hotels in Malaysia published by the Ministry of Tourism (Ministry of Tourism, 2012), a total of 128 hotels were identified. These hotels were located in the northern, central, and southern regions of Peninsular Malaysia. Of these, only 29 hotels consented to participate in our survey. We distributed the survey packets addressed to the HR managers of the respective hotels using either mail or "drop" and "pick-up" method depending on the location of the hotel. Each of the survey packets contains 10 questionnaires to be distributed to frontline employees working in the front office department. Two weeks were given to respondents to complete the questionnaires. After the stipulated period, all 290 questionnaires were collected back. These completed questionnaires were found to be useable and subsequently analyzed.

\section{Measures and Analysis}

Selective hiring was assessed using 5 items adapted from Chuang and Liao(2010) whereas organizational commitment was measured using 9 items adapted from Mowday et al. (1979). The response format was based on a five-point Likert scale ("1" = "strongly disagree" to " 5 " = "strongly agree").Our hypothesis was tested using the Partial Least Squares (PLS) method. The objective of 
PLS-SEM is to maximize the explained variance of the endogenous latent variable by estimating the structural model relationships (Hair, Ringle, \&Sarstedt, 2011). The analysis of the research model was conducted in two stages which begin with the evaluation of measurement model followed by the structural model. The evaluation of the measurement model aims to gauge the reliability and validity of the model whereas the evaluation of the structural model is to test the significance of the path coefficients.

\section{RESULTS}

Descriptive Results

Our participants consisted of 177 (61.0\%) females and $113(39.0 \%)$ males. The ethnic composition is as follows: Malays (69.0\%), Chinese (18.3\%), Indians (11.7\%), and others $(1.0 \%)$. A majority of the respondents $(72.1 \%)$ were secondary school leavers. Slightly less than half $(44.1 \%)$ of the sampled employees were married. The mean values for selected demographic variables are: age (27.5 years), job tenure (4.3 years), organizational tenure (4.4 years). Meanwhile, the descriptive scores for selective hiring (mean=3.85; $S D=0.64$ ) and organizational commitment (mean=3.92; $\mathrm{SD}=0.72$ ) were considered moderate.

\section{Measurement Model Results}

Table 1 presents the result of the measurement model. As shown, all the items' loadings $(0.749$ - 0.884) surpassed Chin's (1998) cut-off value of 0.70 . Likewise, the composite reliability of the constructs $(0.912-0.954)$ exceeded the 0.70 ceiling value recommended by Fornell and Larcker (1981). Therefore, it can be concluded that our measurement model is reliable. We also examined the validity of the measurement model based on its convergent validity and discriminant validity. As depicted in Table 1, all the AVE values (0.676 - 0.699) exceeded Fornell and Larcker's (1981) threshold value of 0.5 , indicating that the measurement model has convergent validity.

Table 1

Results of the Measurement Model

\begin{tabular}{lcccc}
\hline Construct & Items & Loadings & $\begin{array}{c}\text { Composite } \\
\text { Reliability }\end{array}$ & AVE \\
\hline Organizational Commitment & OC 1 & 0.784 & 0.954 & 0.699 \\
& OC 2 & 0.862 & & \\
& OC 3 & 0.808 & & \\
& OC 4 & 0.786 & & \\
& OC 5 & 0.883 & & \\
OC 6 & 0.871 & & \\
Selective Hiring & OC 7 & 0.850 & & \\
& OC 8 & 0.843 & & \\
& OC 9 & 0.833 & & \\
& SH 1 & 0.820 & & \\
& SH 2 & 0.859 & & \\
& SH 3 & 0.884 & & \\
\hline
\end{tabular}




\begin{tabular}{ll}
\hline SH 4 & 0.792 \\
SH 5 & 0.749 \\
\hline
\end{tabular}

Table 2 shows that the square roots of the AVE of the latent variables exceeded the correlations of other constructs. We observed that the loadings for each construct are greater than all of its cross-loadings. Based on the recommendation by Fornell and Larcker (1981), we concluded that the measurement model has adequate discriminant validity.

Table 2

Discriminant Validity of the Measurement Model

\begin{tabular}{lcc}
\hline Variable & $\begin{array}{c}\text { Organizational } \\
\text { Commitment }\end{array}$ & Selective Hiring \\
\hline Organizational commitment & 0.836 & \\
Selective hiring & 0.579 & 0.822 \\
\hline
\end{tabular}

Structural Model Results

The effects of the control variables were also estimated. As portrayed in Table 3, of the seven control variables, academic qualification and marital status were found to have some significant effect on the endogenous variables. However, the R-square changes for both variables were considered negligible based on Cohen's (1988) interpretation. Hence, we decided to exclude the control variables in our hypothesis testing.

\section{Table 3}

Assessment of Control Variables

\begin{tabular}{lccc}
\hline \multirow{2}{*}{ Control Variable } & \multicolumn{3}{c}{ Organizational Commitment } \\
\cline { 2 - 4 } & Beta & t-value & $\mathbf{R}^{2}$ Change \\
\hline Academic Qualification & $-0.192^{* *}$ & 3.746 & 0.036 \\
Age & 0.014 & 0.303 & 0.000 \\
Ethnicity & -0.158 & 1.590 & 0.024 \\
Gender & -0.042 & 0.940 & 0.001 \\
Marital Status & $0.096^{*}$ & 2.009 & 0.009 \\
Job Tenure & 0.027 & 0.497 & 0.000 \\
Organizational Tenure & 0.016 & 0.284 & 0.000 \\
\hline
\end{tabular}

Figure 1 depicts the beta coefficient of the proposed relationship whereby a positive and significant relationship exists between selective hiring and organizational commitment $(\beta=0.579, p<$ 0.01). Therefore, our hypothesis was supported. The results of the structural model also demonstrated that selective hiring was able to explain $33.5 \%$ of the variance in organizational commitment. 
Figure 1

Path Coefficients and R-Square of the Research Model

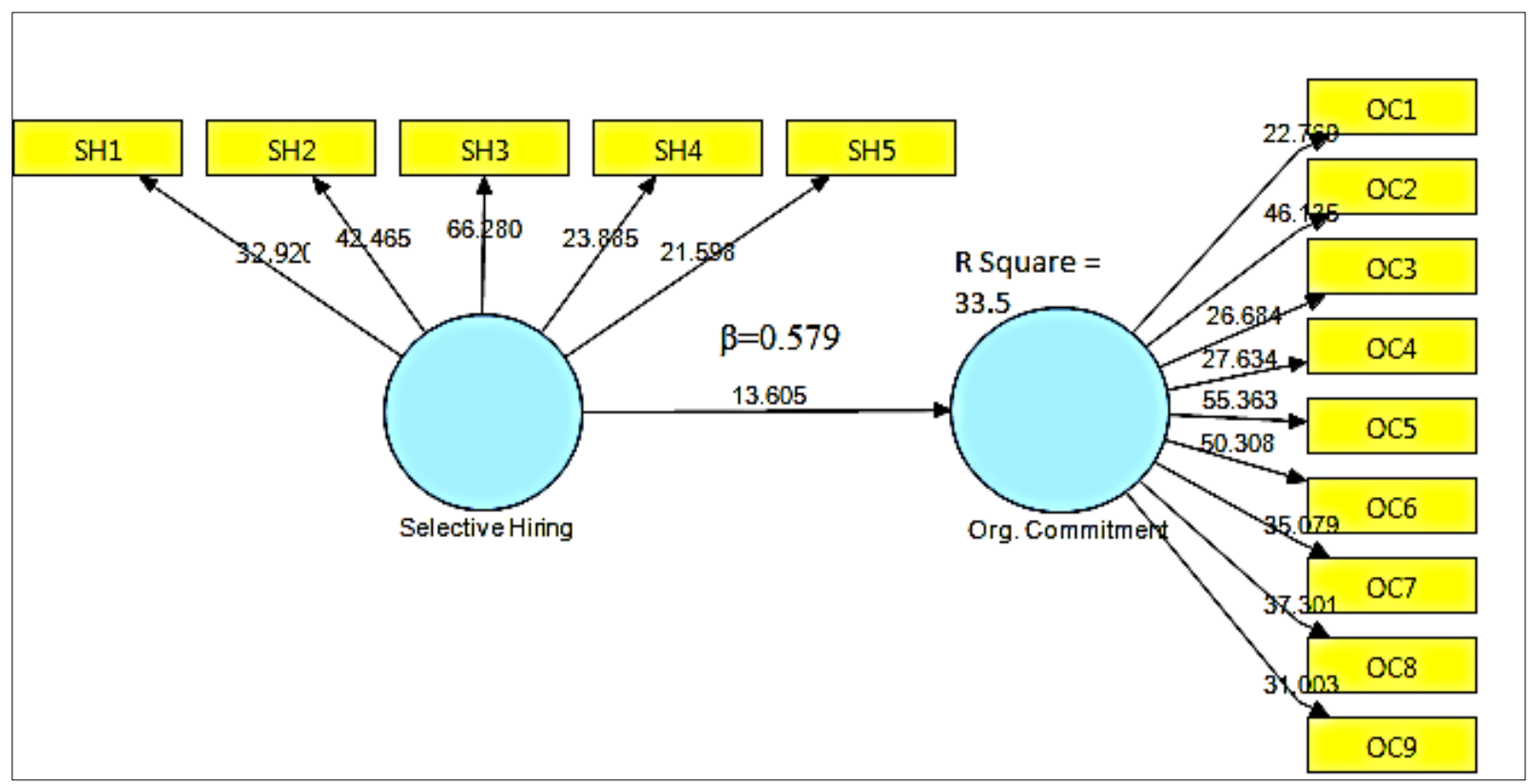

\section{DISCUSSION, IMPLICATIONS, AND LIMITATIONS}

The present study seeks to examine the effect of selective hiring on organizational commitment. Our statistical result provides evidence that selective hiring, an individual HRM practice, has a positive and significant effect on organizational commitment. Our present finding is consistent with that of Caldwell et al. (1990). As noted by Fiorito et al. (2007), selective hiring which suggests a stringent recruitment and selection system involving significant costs and effort conveys a message to those employees who are selected that the organization values them and are committed to take care of them. In a social exchange context (Blau, 1964), employees are likely to feel obligated to repay the organization through increased commitment. In addition, selective hiring implies careful matching between job applicants and the organization's culture, thereby, ensuring a better person-organization fit, which subsequently lead to greater commitment.

For practitioners, our findings suggest that hiring selectivity may foster greater organizational commitment. Specifically, hotels should have a clear and well-defined list of desired values, attitudes, and behaviors. These attributes will enable recruiters to have a better guideline when selecting candidates. Besides, to increase the fit between the candidate and the job, hotel managers should provide a more realistic description about work during the job interview. In this way, job candidates would be able to make better decisions which ultimately lead them to experience greater satisfaction and commitment. Fostering employee commitment would represent one way to reduce employee turnover which has been regarded by previous researchers (Ahmad \&Scott, 2014; Alonso \&O'Neill, 2009) as the greatest challenge faced by the hotel industry.

Although this study makes an important contribution to the hospitality literature, it is limited by two main concerns. First, confining our sample to frontline employees from large hotels in Malaysia may limit generalizability of the findings. Extending the research to include medium and small-sized hotels 
as well as other segments of the hospitality industry such as lodging, restaurants, and theme parks may improve the generalizability of the results. Second, data collected were cross-sectional which limit our ability to make causal inferences. In future, given that commitment may vary over time (Reid, Allen, Riemenschneider, \&Armstrong, 2008), a longitudinal approach would be more fruitful.

\section{REFERENCES}

Ahmad, R., \& Scott, N. (2014). Managing the front office department: Staffing issues in Malaysian hotels. Anatolia: An International Journal of Tourism and Hospitality Research.Vol. 25(1), pp. 24-38.

Allen, N. J., \& Meyer, J. P. (1990). Organizational socialization tactics: A longitudinal analysis of links to newcomers' commitment and role orientation. Academy of Management Journal.Vol. 33(4), pp. 847-858.

Alonso, A.D. \& O'Neill, M.A (2009). Staffing issues among small hospitality businesses: A college town case. International Journal of Hospitality Management. Vol. 28, pp. 573-578.

Aryee, S., Budhwar, P. S., \& Chen, Z. X. (2002). Trust as a mediator of the relationship between organizational justice and work outcomes: Test of a social exchange model. Journal of Organizational Behavior.Vol. 23(3), pp. 267-285.

Berger, F., \& Ghei, A. (1995). Employment tests: A facet of hospitality hiring. The Cornell Hotel and Restaurant Administration Quarterly.Vol. 36(6), pp. 28-35.

Blau, P. M. (1964). Exchange and Power in Social Life. New York: Wiley.

Boon, C., Belschak, F. D., Den Hartog, D. N., \& Pijnenburg, M. (2014). Perceived human resource management practices: Their effect on employee absenteeism and time allocation at work. Journal of Personnel Psychology.Vol. 13(1), pp. 21-33.

Caldwell, D. F., Chatman, J. A., \& O'Reilly, C. A. (1990). Building organizational commitment: A multifirm study. Journal of Occupational Psychology. Vol. 63(3), pp. 245-261.

Chan, A. W., Tong-qing, F., Redman, T., \& Snape, E. (2006). Evaluating the multi-dimensional view of employee commitment: A comparative UK-Chinese study. The International Journal of Human Resource Management. Vol. 17(11), pp. 1873-1887.

Chew, Y. T., \& Wong, S. K. (2008). Effects of mentoring and perceived organizational support on employee commitment and intention to leave: A study among hotel workers in Malaysia. International Journal of Management. Vol. 25(3), pp. 692-779.

Chuang, C.-H., \& Liao, H. (2010). Strategic human resource management in service context: Taking care of business by taking care of employees and customers. Personnel Psychology. Vol. 63(1), pp. 153-196.

Cohen, J. (1988). Statistical Power Analysis for the Behavioral Sciences (2nd ed.). Hillsdale, NJ: Lawrence Erlbaum.

Dessler, G. (1999). How to earn your employees' commitment. Academy of Management Executive. Vol. 13(2), pp. 58-67.

Dittmer, P. R. (2002). Dimenstions of the Hospitality Industry. (3rd ed.). New York: John Wiley and Sons.

Doug, D., Ruth, T., \& Lawson, S. (2001). The role of appraisal, remuneration and training in improving staff relations in the Western Australian accommodation industry: A comparative study. Journal of European Industrial Training. Vol. 25(7), pp. 366 - 373.

Eisenberger, R., Armeli, S., Rexwinkel, B., Lynch, P. D., \& Rhoades, L. (2001). Reciprocation of perceived organizational support. Journal of Applied Psychology.Vol. 86(1), pp. 42-51.

Fiorito, J., Bozeman, D. P., Young, A., \& Meurs, J. A. (2007). Organizational commitment, human resource practices, and organizational characteristics. Journal of Managerial Issues.Vol.19(2), pp. 186-207. 
Fornell, C., \& Larcker, D. F. (1981). Evaluating Structural Equation Models with unobservable variables and measurement error. Journal of Marketing Research.Vol. 18(1), pp. 39-50.

Gouldner, A. W. (1960). The norm of reciprocity: A preliminary statement. American Social Review.Vol. 25, pp. 161-178.

Groves, J., Martin, L., \& Beck, J. (2001). Selection processes for lodging entry-level service employees. The Journal of Applied Hospitality Management.Vol. 3(2), pp. 67-72.

Hair, J. F., Ringle, C. M., \& Sarstedt, M. (2011). PLS-SEM: Indeed a silver bullet. Journal of Marketing Theory and Practice.Vol. 18(2), pp. 139-152.

Harter, J. K., Schmidt, F. L., \& Hayes, T. L. (2002). Business-unit-level relationship between employee satisfaction, employee engagement, and business outcomes: A meta-analysis. Journal of Applied Psychology.Vol. 87(2), pp. 268-279.

Hemdi, M. A. (2009). Investigating hotel employees' organizational commitment: The influence of human resource management practices and perceived organizational support. Journal of Tourism, Hospitality \& Culinary Arts. Vol. 1(3), pp. 1-18.

Huselid, M. A. (1995). The impact of human resource management practices on turnover, productivity and corporate financial performance. Academy of Management Journal.Vol. 38(3), pp. 635-672.

Iplik, F. N., Jilic, K. C., \& Yalcin, A. (2011). The simultaneous effects of person-organization and person-job fit on Turkish hotel managers. International Journal of Contemporary Hospitality Management.Vol. 23(5), pp. 644-661.

Kazlauskaite, R., Buciuniene, I., \& Turauskas, L. (2006). Building employee commitment in the hospitality industry. Baltic Journal of Management.Vol. 1(3), pp. 300-314.

Kennedy, D. J., \& Berger, F. (1994). Newcomer socialization: Oriented to facts or feelings? Cornell Hotel and Restaurant Administration Quarterly.Vol. 35(6), pp. 58-71.

Kusluvan, S., Kusluvan, Z., Ilhan, I., \& Buyruk, L. (2010). The human dimension: A review of human resources management issues in the tourism and hospitality industry. Cornell Hospitality Quarterly.Vol. 51(2), pp. 171-214.

Lee, Y.-K., Nam, J. H., Park, D. H., \& Lee, K. A. (2006). What factors influence customer-oriented prosocial behavior of customer-contact employees? Journal of Services Marketing.Vol. 20(4), pp. 251-264.

Lockyer, C., \& Scholarios, D. (2004). Selecting hotel staff: why best practice does not always work. International Journal of Contemporary Hospitality Management.Vol. 16(2), pp. 125-135.

Louis, M. R. (1980). Surprise and sense making: What newcomers experience in entering unfamiliar organizational settings. Administrative Science Quarterly. Vol. 25(2), pp. 226-251.

Lundberg, C. C., \& Young, C. A. (1997). Newcomer socialization: Critical incidents in hospitality organizations. Journal of Hospitality \& Tourism Research.Vol. 21(2), pp. 58-74.

Ma, E., \& Qu, H. (2011). Social exchanges as motivators of hotel employees' organizational citizenship behavior: The proposition and application of a new three-dimensional framework. International Journal of Hospitality Management. Vol. 30(3), pp. 680-688.

Mathieu, J. E., \& Zajac, D. M. (1990). A review and meta-analysis of the antecedents, correlates, and consequences of organizational commitment. Psychological Bulletin. Vol. 108(2), pp. 171-194.

Maxwell, G., \& Steele, G. (2003). Organisational commitment: A study of managers in hotels. International Journal of Contemporary Hospitality Management.Vol. 15(7), pp. 362-369.

Meyer, J. P., \& Smith, C., A. (2000). HRM practices and organizational commitment: Test of a mediation model. Canadian Journal of Administrative Sciences. Vol. 17(4), pp. 319-331.

Meyer, J. P., Stanley, D. J., Herscovitch, L., \& Topolnytsky, L. (2002). Affective, continuance, and normative commitment to the organization: A meta-analysis of antecedents, correlates, and consequences. Journal of Vocational Behavior.Vol. 61(1), pp. 20-52.

Ministry of Tourism. (2011). Malaysia Tourism Key Performance Indicators 2009. Kuala Lumpur.

Ministry of Tourism. (2012). Malaysia Accommodation Directory 2010/2011. 
Ministry of Tourism and Culture Malaysia. (2014). History of Visit Malaysia Year. [Online]. Retrieved January 20, 2014, from http://www.vmy2014.com/about-vmy2014/history-of-visit-malaysia-year

Morrison, E. W. (1996). Organizational citizenship behavior as a critical link between HRM practices and service quality. Human Resource Management. Vol. 35(4), pp. 493-512.

Mowday, R. T. (1998). Reflections on the study and relevance of organizational commitment. Human Resource Management Review.Vol. 8(4), pp. 387-401.

Mowday, R. T., Steers, R. M., \& Porter, L. W. (1979). The measurement of organizational commitment. Journal of Vocational Behavior. Vol. 14(2), pp. 224-247.

O'Reilly, C. A., \& Chatman, J. (1986). Organizational commitment and psychological attachment: The effects of compliance, identification, and internalization on prosocial behavior. Journal of Applied Psychology. Vol. 71(3), pp. 492-499.

Paulin, M., Ferguson, R. J., \& Bergeron, J. (2006). Service climate and organizational commitment: The importance of customer linkages. Journal of Business Research.Vol. 59(8), pp. 906-915.

Reichers, A. E. (1985). A review and reconceptualization of organizational commitment. Academy of Management Review.Vol. 10(3), pp. 465-476.

Reid, M. F., Allen, M. W., Riemenschneider, C. K., \& Armstrong, D. J. (2008). The role of mentoring and supervisor support for State IT employees' affective organizational commitment. Review of Public Personnel Administration.Vol. 28(1), pp. 60-78.

Roehl, W. S., \& Swerdlow, S. (1999). Training and its impact on organizational commitment among lodging employees. Journal of Hospitality \& Tourism Research.Vol. 23(2), pp. 176-194.

Schneider, B., \& Bowen, D. E. (1985). Employee and customer perceptions of service in banks: Replication and extension. Journal of Applied Psychology.Vol. 70(3), pp. 423-433.

Schuler, R. S., \& Jackson, S. E. (1987). Linking competitive strategies with human resource management practices. The Academy of Management Executive.Vol. 1(3), pp. 207-219.

Singh, J. (1998). Striking a balance in boundary-spanning positions: An investigation of some unconventional influences of role stressors and job characteristics on job outcomes of salespeople. The Journal of Marketing.Vol. 62(3), pp. 69-86.

Snape, E., \& Redman, T. (2010). HRM practices, organizational citizenship behaviour, and performance: A multi-level analysis. Journal of Management Studies. Vol. 47(7), pp. 12191247.

Tourism Malaysia. (2014). Malaysia Hotels \& Rooms Supply. [Online]. Retrieved January 20, 2014, from http://www.tourism.gov.my/facts figures/

Verquer, M. L., Beehr, T. A., \& Wagner, S. H. (2003). A meta-analysis of relations between personorganization fit and work attitudes. Journal of Vocational Behavior.Vol. 63(3), pp. 473-489.

Walsh, K., \& Taylor, M. S. (2007). Developing In-House Careers and Retaining Management Talent: What Hospitality Professionals Want from Their Jobs. Cornell Hotel and Restaurant Administration Quarterly.Vol. 48(2), pp. 163-182.

Wanous, J. P., \& Reichers, A. E. (2000). New employee orientation programs. Human Resource Management Review.Vol. 10(4), pp. 435-451.

Yang, Y.-C. (2012). High-involvement human resource practices, affective commitment, and organizational citizenship behaviors in service setting. The Service Industries Journal.Vol. 32(8), pp. 1209-1227.

\section{ACKNOWLEDGEMENT}

The authors would like to express their gratitude to Universiti Sains Malaysia for providing the grant (1001/PMGT/816193) to fund this research. 